\title{
BURIAL AND THERMAL HISTORY OF THE CAUVERY BASIN, SRI LANKA: A BASIN MODELING APPROACH
}

\author{
UPUL PREMARATHNE ${ }^{1 *}$ \\ ${ }^{1}$ Department of Oceanography and Marine Geology, Faculty of Fisheries and Marine \\ Sciences \& Technology, University of Ruhuna, Wellamadama, Matara, Sri Lanka \\ *Corresponding Author: e-mail-premarat@yahoo.com \\ (Received 23 $3^{\text {rd }}$ December 2019; accepted $13^{\text {th }}$ February 2020)
}

\begin{abstract}
Cauvery Basin is located between the southeastern onshore areas of India and the northwestern onshore areas of Sri Lanka. The basin has evolved due to crustal extension between India and Sri Lanka as a result of the breakup of East Gondwana. Rifting began in the Hauterivian and continued until the Cenomanian. The Indian side of the basin accommodates commercially viable oil and natural gas deposits. Hydrocarbon exploration in the Sri Lankan sector of the basin commenced as early as 1957. Six exploration wells were drilled in Sri Lanka during 1972 to 1981. None of these wells encountered any economically viable hydrocarbon deposits. Little further exploration took place in the Cauvery Basin in Sri Lanka to this date. However, the Sri Lankan government has indicated its plan to resume hydrocarbon exploration in the Cauvery Basin after the discovery of natural gas deposits in Mannar Basin in 2011. The Mannar Basin is considered to be the southern extension of the Cauvery Basin. Only a handful of studies is available on the Sri Lanka sector of the basin in the public domain, though plenty is available on the Indian counterpart. The objective of this study is to understand the burial and thermal history of the Sri Lankan part of the Cauvery Basin based on basin modeling techniques. Petromod 1D software (version. 12.2) was used to simulate the burial and thermal history of the Pesalai-1, Palk Bay-1, Delft-1 and Pedro1 wells using data from unpublished well reports held at Petroleum Resources Development Secretariat in Sri Lanka. In addition, data available in the public domain were also used to derive some input data and boundary conditions. Results of the study show that southern part of the Cauvery Basin in Sri Lanka has experienced higher heat flows. The present-day geothermal gradient in Pesalai-1 and Palk Bay-1, Delft-1 and Pedro- 1 wells are $25.5^{\circ} \mathrm{C} / \mathrm{km}, 25.0^{\circ} \mathrm{C} / \mathrm{km}, 21.3^{\circ} \mathrm{C} / \mathrm{km}$ and $18.5^{\circ} \mathrm{C} / \mathrm{km}$, respectively. The present-day geothermal gradient of the basin increases from north to south. The highest bottom hole temperature $\left(\sim 90^{\circ} \mathrm{C}\right)$, was recorded in Pesalai-1 well. The Pesalai area has experienced higher heat flows than the Palk Bay area. Current heat flows in Pesalai and Palk Bay areas are around $52 \mathrm{~mW} / \mathrm{m}^{2}$ and $48 \mathrm{~mW} / \mathrm{m}^{2}$, respectively. The pre-rift heat flow in the Sri Lankan sector of the Cauvery Basin varied between $46-40 \mathrm{~mW} / \mathrm{m}^{2}$. Area where the Delft-1 and Pedro-1 well are located have undergone upliftment during the Albian to the end of the Eocene (around $100-34 \mathrm{Ma}$ ). The Sri Lankan Cauvery Basin has had a relatively a higher sediment influx after the Eocene. The sediment thickness decreases towards the north of the basin. Sediments penetrated by the Palk Bay-1, Delft-1 and Pedro-1 wells are thermally immature. However, Albian sediment penetrated by Pesalai- 1 well is marginally matured and has just entered the oil window.
\end{abstract}

Keywords: Cauvery Basin, Heat flow, Pesalai, Palk Bay, Sri Lanka

\section{INTRODUCTION}

Cauvery Basin is located between the southeastern onshore areas of India and the northwestern onshore area of Sri Lanka. The Indian side of the Cauvery Basin extends over 62,500 Sq.km onshore and offshore up to 200 $\mathrm{m}$ isobath (Chaudhuri et al., 2010). The Sri
Lankan side of the basin lies over 15,000 Sq. $\mathrm{km}$ in northwest onshore and offshore areas up to $200 \mathrm{~m}$ isobaths. Both oil and natural gas is produced from onshore and offshore fields in the Indian side of the basin. Therefore, it is considered as a category one basin. 


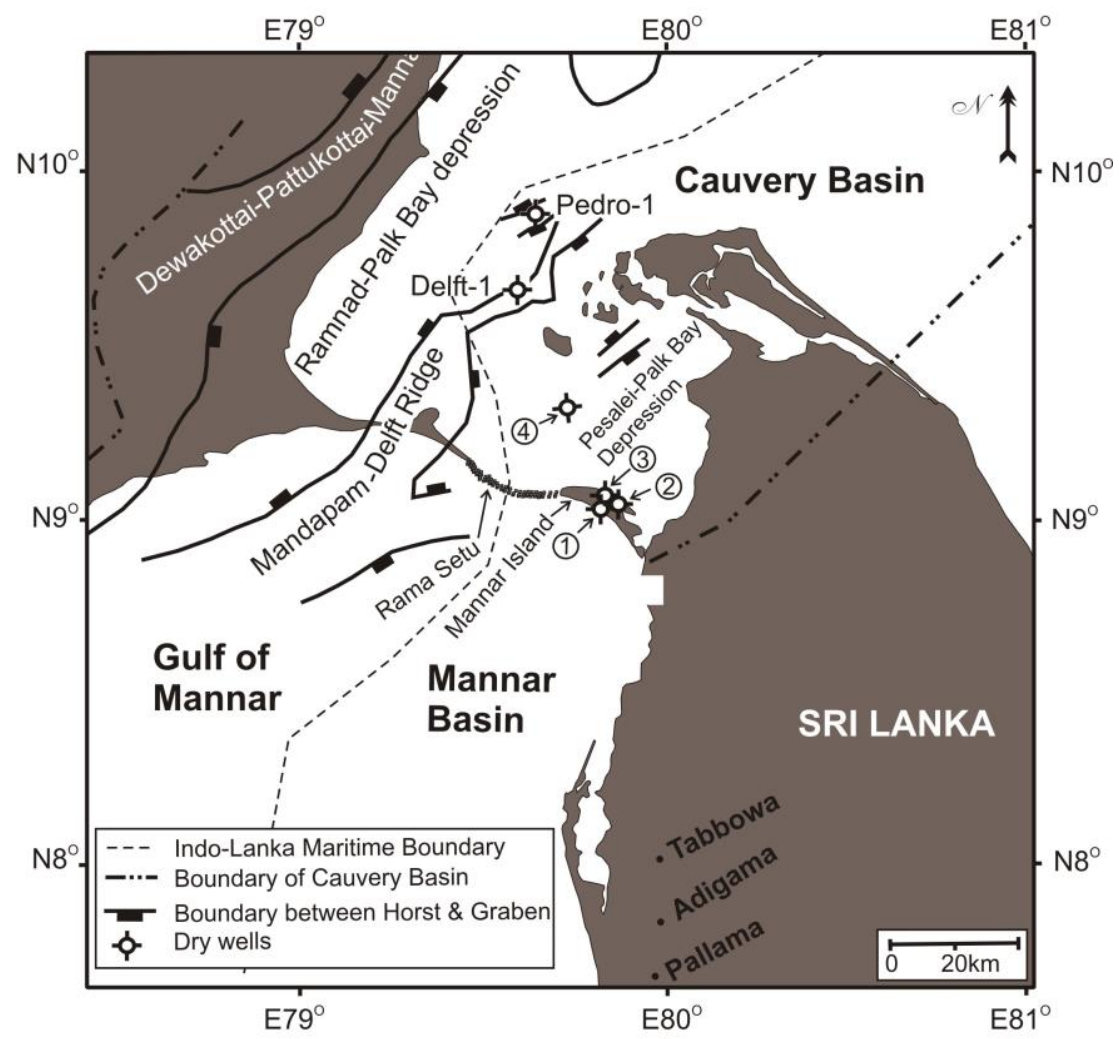

Fig. 1. Sri Lankan side of the Cauvery Basin and hydrocarbon exploration wells drilled in it (modified after Premaratne et al., 2015) Encircled 1, 2, 3, and 4 in the Figure refer to Pesalai-1, 2 and 3 wells, and Palk Bay-1 well, respectively.

Hydrocarbon exploration in the Sri Lankan side of the Cauvery Basin began as early as 1957. The first exploration well in Sri Lanka was drilled in 1974 at Pesalai area on Mannar island located in the northwest of Sri Lanka (Fig. 1). Later, five more exploration wells were drilled in the Sri Lankan side of the basin. However, all of these wells were abandoned as dry holes. Little further exploration took place in the Sri Lankan side of the Cauvery Basin to this date. PH-9-1 well in the Ramnad-Balk Bay-Nagapattinam depression in the Indian side of the Cauvery Basin is located around 21 $\mathrm{km}$ away from the Indo-Lanka maritime boundary (Ramana et al., 1995). It is the hydrocarbon discovery well in India located closest to Sri Lanka.

The Sri Lankan Government has indicated its interest to resume hydrocarbon exploration in the Cauvery Basin under its jurisdiction after the discovery of natural gas in the Mannar Basin in 2011. These discoveries confirmed the occurrence of an active petroleum system in the Mannar Basin (Mohapatra et al., 2012; Premarathne et al., 2013). The Mannar Basin in Sri Lanka, which is located immediately to the south of the Cauvery Basin is considered to be a sub basin of the Cauvery Basin by some researches (eg. Murthy et al., 2008; Rana et al., 2008; Rao, et al., 2010). Though there have been many studies on geology, tectonic setting and hydrocarbon prospectivity of the Indian side of the Cauvery Basin (eg. Sastri et al., 1973; 1981; Chandra et al., 1991; Ramana et al., 1995; Murthy et al., 2008; Rana et al., 2008; Lal et al., 2009; Rao, et al., 2010; Chaudhuri et al., 2009; Bastia and Radhakrishna, 2012), only a handful of studies are available on the Sri Lankan side of the Cauvery Basin (eg. Cantwell et al., 1978; Premarathne, 2008, 2015, 2017). Cantwell et al., (1978) has addressed stratigraphy and source rock potential and thermal maturity of some potential source rocks penetrated by the exploration wells drilled in the Sri Lankan sector of the Cauvery Basin. Premarathne $(2015,2017)$, on the other hand, has addressed petroleum geology and present-day heat flows. The objective of this study is to understand the burial and thermal history of the Sri Lankan sector of the Cauvery Basin based on basin modeling techniques. 


\section{TECTONIC SETTING}

Cauvery Basin is a pericretonic failed rift basin (Sastri et al., 1973, 1981), which has been originated due to the fragmentation of East Gondwana (Katz, 1978; Sastri et al., 1981; Lal et al., 2009). Separation of Gondwana into east and west sections was initiated in the Middle Jurassic around $167 \mathrm{Ma}$ (Reeves et al., 2002). The beak up of the East Gondwana commenced in the Early Cretaceous around $130 \mathrm{Ma}$ (Lal et al., 2009). This event was followed by the northward movement of the landmass comprised of India, Madagascar and Sri Lanka (Torsvik et al., 2002). Data from the Pesalai-1 well suggest that the Mannar island of Sri Lanka, which is currently located at $8^{\circ}$ North latitude, was located $16^{\circ}$ South latitude in the early Cretaceous (Cantwell et al., 1978). Rifting between Indo-Lanka landmasses has occurred as part of Sri Lanka's counter clockwise rotation around northern part of the island acting as a pivot (Yoshida, et al., 1992). This rotation has continued until about $96 \mathrm{Ma}$ (Chari et al., 1995). The Syn-rift phase of the Cauvery Basin lasted from the late Jurassic to the Cenomanian epoch. (Chakraborty and Sarkar, 2018; Raju et al., 2018: Chaudhuri et al., 2010). Numerous down-to-basin extensional faulting took place in the Cauvery Basin due to rifting (Murthy et al., 2008). The basin is considered to have entered into a thermal sag phase after $96 \mathrm{Ma}$.

\section{BASIN MODELING SOFTWARE, INPUT DATA AND BOUNDARY CONDITIONS}

\section{SOFTWARE}

Petromod 1D software (version 12.2) was used to simulate the burial and thermal history of the Pesalai-1, Palk Bay-1, Delft-1 and Pedro-1 wells, which are located in northwestern onshore and offshore area of Sri Lanka (Fig. 1 for well locations).

\section{LITHOLOGY AND BIOSTRATIGRAPHY OF WELLS}

Lithological descriptions in unpublished well reports held at Petroleum Resources
Development Secretariat (PRDS) in Sri Lanka and biostratigraphy data reported by Cantwell et al. (1978) for the wells were used in this study. The Cauvery Basin has erosional unconformities with greater hiatuses (Fig. 2). Erosional thicknesses were estimated based on average sedimentation rates of the formations immediately above and below each unconformity. Tables 1 and 2 summarize the main input data.

\section{HEAT FLOW}

Parsons and Sclater (1977) proposed a typical heat flow pattern for rift basins. Accordingly, the heat flow of a rift basin gradually increases during the syn-rift period. It reaches a maximum value at the end of rifting and then declines exponentially during the post-rift period. As proposed by Chakraborty and Sarkar, (2018); Raju et al. (2018); Chaudhuri et al. (2010), the end of rifting period of the Cauvery Basin is considered to be 96 Ma. Premarathne (2017) has reported the presentday heat flows in the Pesalai-Palk Bay depression to be $39-50 \mathrm{mWm}^{-2}$, while that in the Sri Lankan sector of the Ramnad-Palk Bay depression to be 37- $65 \mathrm{mWm}^{-2}$. The pre-rift heat flow in the Cauvery Basin has not been fully understood. However, Premarathne et al. (2015) reported that the pre-rift heat flow in the adjacent Mannar Basin was $50.2 \mathrm{~mW} / \mathrm{m}^{2}$. This is further supported by low vitrinite reflectance values reported for Late Jurassic sediments in a couple of small Grabens located at Tabbowa and Andigama (Fig. 1) in Sri Lanka by Ratnayake and Sampei (2015). Therefore, the pre rift heat flow in the Cauvery Basin could be around $50 \mathrm{~mW} / \mathrm{m}^{2}$. Considering the above-mentioned factors (i.e. Present-day and pre rift heat flows, the time when the rifting was stopped and the typical heat flow pattern of a rift basin), different heat flow scenarios were modelled until the modelled kerogen maturation profiles for each well coincides with the measured kerogen maturation profiles of respective wells. Vitrinite reflectance data is not available for the Perdo-1 well. Therefore, the heat flow history at the Delft well was used for the Perdo-1 well, since the two wells are located close by. 


\section{PALEO WATER DEPTH}

Biostratigraphy data available in well reports held at the PRDS, some bathymetry data of Cretaceous sediments from the Ramnad-Palk Bay depression reported by Chandra et al. (1991) and Eustatic Sea level changes reported by Pitman (1978) were used to estimate the depositional water depths of early Cretaceous
( 130 Ma) to Recent sediments penetrated by Pesalai-1, Palk Bay-1, Delft-1 and Pedro-1 wells. Relatively short-term $(<\quad 10 \quad \mathrm{Ma})$ variations of depositional water depths caused by climate change and tectonic activities were not considered in this study.

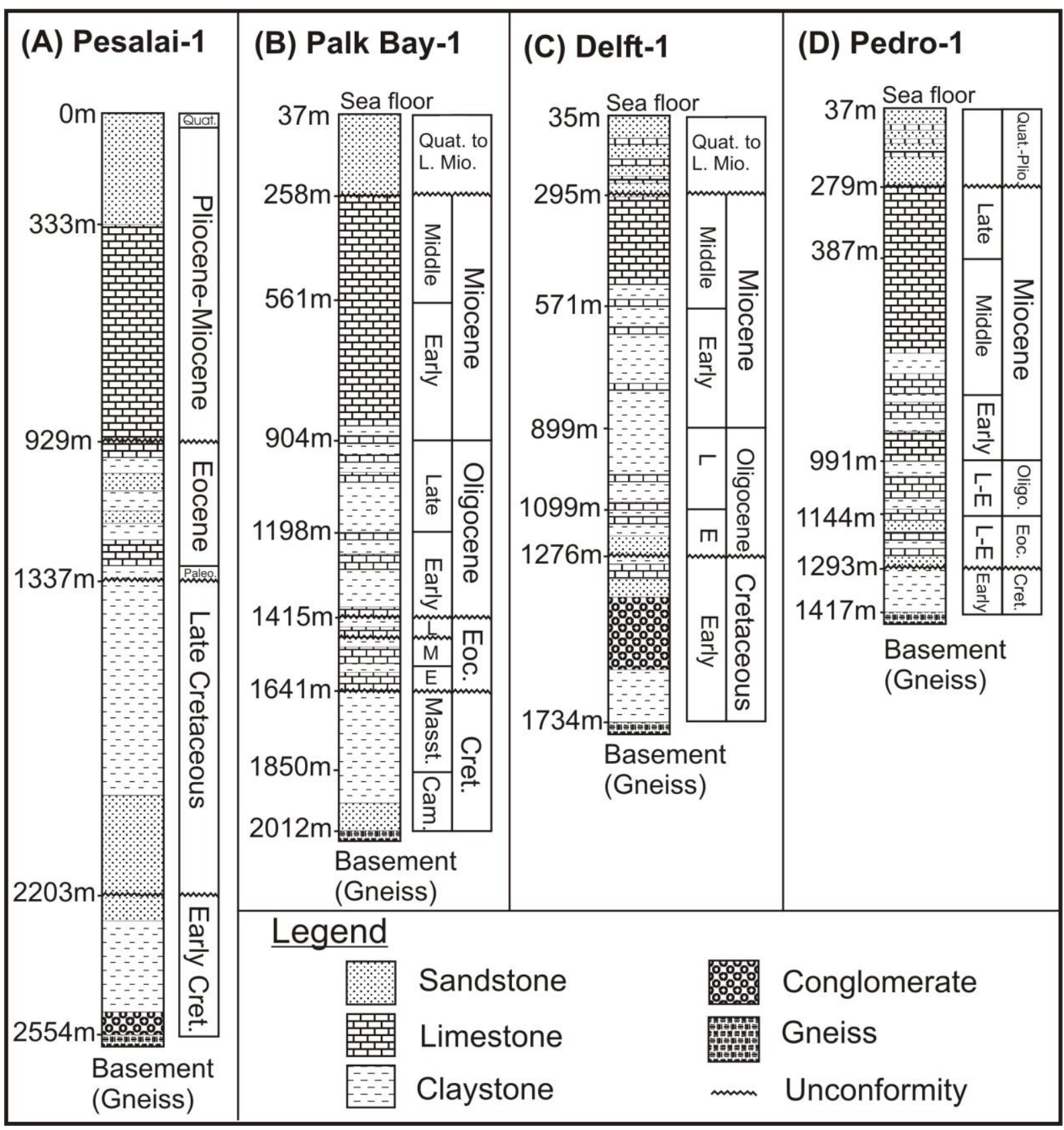

Fig. 2. Generalized stratigraphic sections of Pesalai-1, Palk Bay-1, Delft-1 and Pedro-1 wells (modified after Cantwell et al., 1978, and Sastri et al., 1981). Quat. = Quaternary; Plio = Pliocene; Mio. $=$ Miocene $;$ Eoc.$=$ Eocene $;$ Palio.$=$ Pliocene $;$ Cret.$=$ Cretaceous $;$ Masst.$=$ Maastrichtian $;$ Camp. = Campanian $E=$ Early $M=$ Middle $L=$ Late . 
Table 1. Input data used in this study for Pesalai -1 and Palk Bay-1 wells $($ Thick. = formation thickness, Depo. = deposition, Quat. = Quaternary, Plio = Pliocene, Mio. = Miocene, Turo. = Turonian, Alb. Albian, Apt and Aptian. L., M., and E., stand for Late, Middle and, respectively).

\section{Pesalai -1}

\begin{tabular}{|c|c|c|c|c|c|c|c|c|c|}
\hline Layer & $\begin{array}{l}\text { Top } \\
(\mathbf{m})\end{array}$ & $\begin{array}{c}\text { Base } \\
\text { (m) }\end{array}$ & $\begin{array}{c}\text { Thick. } \\
\text { (m) }\end{array}$ & $\begin{array}{c}\text { Eroded } \\
(\mathbf{m})\end{array}$ & $\begin{array}{c}\text { Depo. } \\
\text { from (Ma) }\end{array}$ & $\begin{array}{c}\text { Depo. } \\
\text { to (Ma) }\end{array}$ & $\begin{array}{c}\text { Eroded } \\
\text { from (Ma) }\end{array}$ & $\begin{array}{l}\text { Eroded } \\
\text { to (Ma) }\end{array}$ & Lithology \\
\hline Quaternary & 0 & 50 & 50 & - & 2.6 & 0 & - & - & Sandstone (quartzite, typical) \\
\hline Plio. to L. Mio & 50 & 333 & 283 & - & 11.6 & 2.6 & - & - & Sandstone (quartzite, typical) \\
\hline M. to E. Mio. & 333 & 929 & 596 & - & 23 & 11.6 & - & - & Marl \\
\hline Eocene & 929 & 1287 & 358 & 176 & 56 & 33.9 & 33.9 & 23 & Sandstone (arkose, dolomite rich) \\
\hline Paleocene & 1287 & 1337 & 50 & - & 58 & 56 & - & - & Shale (typical) \\
\hline Camp. to Turo. & 1337 & 2000 & 663 & 361 & 92 & 70 & 70 & 58 & Shale (typical) \\
\hline Cenomanian & 2000 & 2203 & 203 & - & 100 & 92 & - & - & Sandstone (typical) \\
\hline Albian_1 & 2203 & 2298 & 95 & 63 & 105 & 102 & 102 & 100 & Sandstone (typical) \\
\hline Alnian -2 & 2298 & 2454 & 156 & - & 110 & 105 & - & - & Shale (typical) \\
\hline Albian_3 & 2454 & 2554 & 100 & - & 113 & 110 & - & - & Conglomerate (typical) \\
\hline
\end{tabular}

\section{Palk Bay -1}

\begin{tabular}{|c|c|c|c|c|c|c|c|c|c|}
\hline Layer & $\begin{array}{l}\text { Top } \\
(\mathbf{m})\end{array}$ & $\begin{array}{c}\text { Base } \\
(\mathbf{m})\end{array}$ & $\begin{array}{c}\text { Thick. } \\
\text { (m) }\end{array}$ & $\begin{array}{c}\text { Eroded } \\
(\mathbf{m})\end{array}$ & $\begin{array}{c}\text { Depo. } \\
\text { from (Ma) }\end{array}$ & $\begin{array}{c}\text { Depo. } \\
\text { to (Ma) }\end{array}$ & $\begin{array}{c}\text { Eroded } \\
\text { from (Ma) }\end{array}$ & $\begin{array}{l}\text { Eroded } \\
\text { to }(\mathrm{Ma})\end{array}$ & Lithology \\
\hline Quat. to L. Mio. & 37 & 258 & 221 & - & 9 & 0 & - & - & Sandstone (quartzite, typical) \\
\hline M. -E. Mio. & 258 & 904 & 646 & - & 23 & 9 & - & - & Marl \\
\hline Oligocene & 904 & 1415 & 511 & - & 33.9 & 23 & - & - & Shale (typical) \\
\hline Eocene & 1415 & 1641 & 226 & - & 56 & 33.9 & - & - & Limestone (shaly) \\
\hline Maastrichtian & 1641 & 1850 & 209 & 310 & 72 & 67 & 67 & 56 & Shale (typical) \\
\hline Campanian & 1850 & 1931 & 81 & - & 75 & 72 & - & - & Shale (typical) \\
\hline Campanian & 1931 & 2012 & 81 & - & 78 & 75 & - & - & Sandstone (typical) \\
\hline
\end{tabular}


Table 2. Input data used in this study for Pesalai -1 and Palk Bay-1 wells (abbreviations are the same as that in Table 1)

\section{Delft -1}

\begin{tabular}{lccccccccc}
\hline Layer & $\begin{array}{c}\text { Top } \\
(\mathbf{m})\end{array}$ & $\begin{array}{c}\text { Base } \\
(\mathbf{m})\end{array}$ & $\begin{array}{c}\text { Thick. } \\
(\mathbf{m})\end{array}$ & $\begin{array}{c}\text { Eroded } \\
(\mathbf{m})\end{array}$ & $\begin{array}{c}\text { Depo. } \\
\text { from (Ma) }\end{array}$ & $\begin{array}{c}\text { Depo. } \\
\text { to (Ma) }\end{array}$ & $\begin{array}{c}\text { Eroded } \\
\text { from (Ma) }\end{array}$ & $\begin{array}{c}\text { Eroded } \\
\text { to (Ma) }\end{array}$ \\
\hline Quat. to Plio. & 35 & 295 & 260 & - & 5.3 & 0 & - & - & Sandstone (typical) \\
M. Mioene & 295 & 571 & 276 & 216 & 16 & 10 & 10 & Lithology \\
E. Miocene & 571 & 899 & 328 & - & 23 & 16 & - & - & Shale (typical) \\
L. Oligocene & 899 & 1099 & 200 & - & 28 & 23 & - & - & Shale (typical) \\
E. Oligocene & 1099 & 1213 & 114 & - & 31.8 & 28 & - & - & Limestone (shaly) \\
E. Oligocene & 1213 & 1276 & 63 & - & 33.9 & 31.8 & - & Sandstone (clay rich) \\
Albian & 1276 & 1322 & 46 & 1650 & 101.6 & 100 & 100 & 33.9 & Limestone (ooid grainstone) \\
Albian & 1322 & 1392 & 70 & - & 104 & 101.6 & - & - & Sandstone (typical) \\
Albian & 1392 & 1592 & 200 & - & 111 & 104 & - & - & Conglomerate (typical) \\
Alb.-Apt. & 1592 & 1734 & 142 & - & 116 & 111 & - & Shainstone) & - \\
\hline
\end{tabular}

\section{Pedro-1}

\begin{tabular}{|c|c|c|c|c|c|c|c|c|c|}
\hline Layer & $\begin{array}{l}\text { Top } \\
\text { (m) }\end{array}$ & $\begin{array}{c}\text { Base } \\
(\mathbf{m})\end{array}$ & $\begin{array}{c}\text { Thick. } \\
\text { (m) }\end{array}$ & $\begin{array}{c}\text { Eroded } \\
(\mathbf{m})\end{array}$ & $\begin{array}{c}\text { Depo. } \\
\text { from (Ma) }\end{array}$ & $\begin{array}{c}\text { Depo. } \\
\text { to (Ma) }\end{array}$ & $\begin{array}{c}\text { Eroded } \\
\text { from (Ma) }\end{array}$ & $\begin{array}{l}\text { Eroded } \\
\text { to }(\mathrm{Ma})\end{array}$ & Lithology \\
\hline Quat. - Plio. & 37 & 279 & 242 & - & 5.3 & 0 & - & - & $\begin{array}{l}\text { Sandstone (typical) } \\
\text { Limestone (Waulsortian }\end{array}$ \\
\hline Miocene & 279 & 660 & 381 & - & 14.8 & 5.3 & - & - & mound) \\
\hline Miocene & 660 & 713 & 53 & - & 16.1 & 14.8 & - & - & Shale (typical) \\
\hline Miocene & 713 & 991 & 278 & - & 23 & 16.1 & - & - & Limestone (shaly) \\
\hline Oligocene & 991 & 1051 & 60 & - & 27.26 & 23 & - & - & Shale (typical) \\
\hline Oligocene & 1051 & 1081 & 30 & - & 29.39 & 27.26 & - & - & Limestone (ooid grainstone) \\
\hline Oligocene & 1081 & 1144 & 63 & - & 33.9 & 29.39 & - & - & Shale (typical) \\
\hline Eocene & 1144 & 1293 & 149 & - & 48 & 33.9 & - & - & Sandstone (clay rich) \\
\hline Albian & 1293 & 1417 & 124 & 920 & 108 & 102 & 102 & 48 & Shale (typical) \\
\hline
\end{tabular}




\section{SURFACE TEMPERATURES}

Zakharov et al. (2009) reported that the average surface temperatures in the Cauvery Basin and southern Indian near-bottom shelf water, during the Albian and Maastrichtian to be $17^{\circ} \mathrm{C}$ and $21^{\circ} \mathrm{C}$, respectively. However, a data set for continuous variation of surface temperatures in the northwestern part of Sri Lanka from the early Cretaceous to the present is not available. Therefore, variations of surface temperatures in the study area for the last $130 \mathrm{Ma}$ (Fig. 3) were generated using an algorithm proposed by Wygrala (1989). However, surface temperatures generated for the Albian and Maastrichtian time based on this algorithm show around $4^{\circ} \mathrm{C}$ over estimation for the Albian and $3^{\circ} \mathrm{C}$ under estimation for the Maastrichtian, compared to the surface temperatures reported by Zakharov et al. (2009) for the two-time periods, respectively. The current average surface temperature in the Pesalai area is around $28^{\circ} \mathrm{C}$.
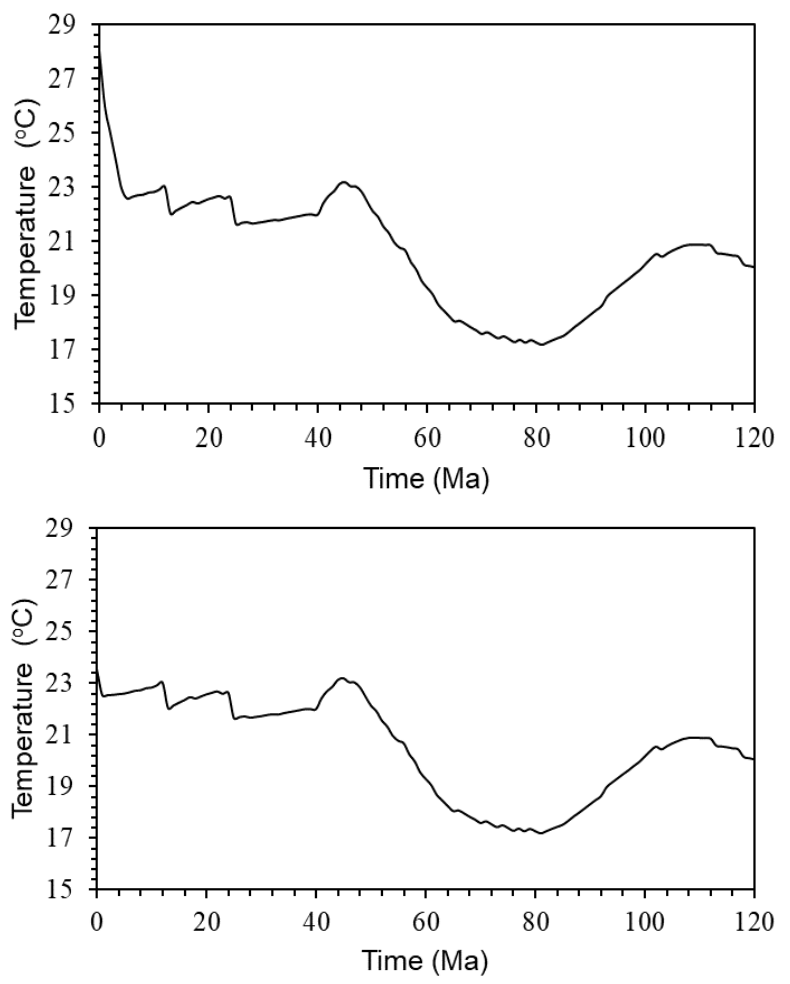

Fig. 3. Change in Surface Temperature and Ocean Bottom Temperatures of (A) Pesalai-1, (B) Palk Bay-1, Delft-1 and Pedro-1 Wells Used In This Study (After Wygrala, 1989).

\section{RESULTS AND DISCUSSION}

\section{CALIBRATION OF HEAT FLOW HISTORY}

Optimized heat flow histories for the Pesalai-1, Palk Bay-1, and Delft-1 wells are shown in Fig 4. Since modeled and observed kerogen maturation profiles (Fig. 5) for each well roughly agree, it could be inferred that the optimized heat flow trends shown in Fig. 4 are reasonably accurate. However, it should be noted that the accuracy of the optimized heat flow trends depends on the accuracy of assumed ocean bottom/surface temperatures (Table 1), the thermal conductivity of rocks, the sediment compaction models etc., for which default values in the software data base were used in this study.

The optimized heat flow histories showed that the Pesalai area on Mannar island (Fig. 1), where the Pesalai-1 well was located, had experienced relatively high heat flows compared to the Palk Bay-1 and Delft-1 well locations. The optimized present-day heat flows at the Pesalai-1, Palk Bay-1 and Delft-1 wells were around $44 \mathrm{~mW} / \mathrm{m}^{2}, 39 \mathrm{~mW} / \mathrm{m}^{2}$, and $37 \mathrm{~mW} / \mathrm{m}^{2}$, respectively. The optimized pre-rift heat flows at the Pesalai-1, Palk Bay-1 and Delft-1 well locations were 46, 42, and $40 \mathrm{~mW} / \mathrm{m}^{2}$, respectively. The maximum heat follows reported at the Pesalai-1, Palk Bay-1 and Delft-1 wells at the end of the rifting period around 90 Ma were, 55, 47, $43 \mathrm{~mW} / \mathrm{m}^{2}$, respectively.

Palaeo-heat flows of the Cauvery Basin increasing from the north to the south could be related to the crustal extension between IndoLanka Land masses that happened in an increasing manner towards south due to the counter-clockwise rotation of Sri Lanka during rifting from India. Increasing stratigraphic thickness from north to south of the Cauvery Basin in Sri Lanka supports this hypothesis. Similar observation was made in the adjacent Mannar Basin by Premarathne et al. (2016). 
(a)

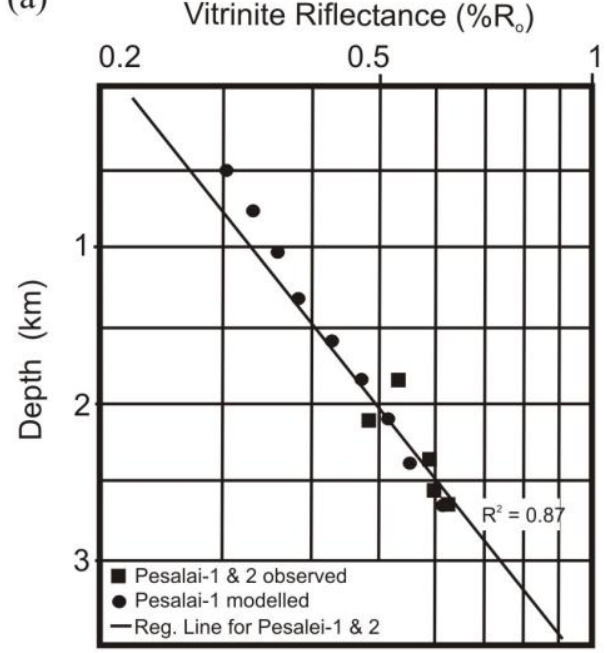

(c)



(b) Vitrinite Riflectance $\left(\% R_{\mathrm{o}}\right)$



(d) Vitrinite Riflectance $\left(\% R_{\mathrm{o}}\right)$



Fig. 4. Modeled and observed vitrinite reflectance (VR) data for the (a) Pesalai-1 (b) Palk Bay-1, (c) Delf-1 and (d) Pedro-1 wells.

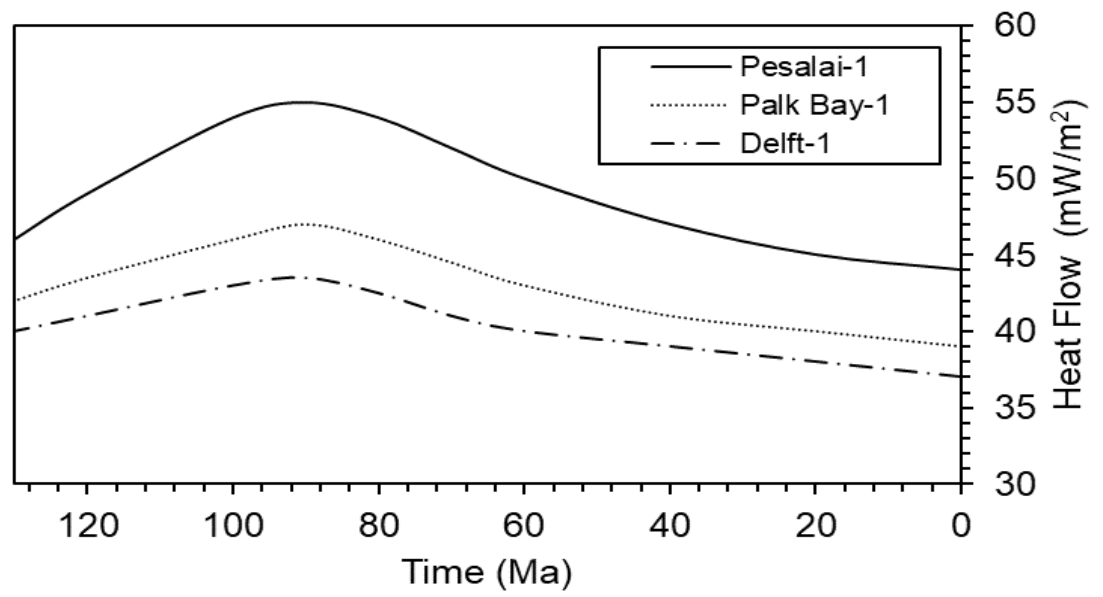

Fig.5. Optimised heat flow histories at the Pesalai-1, Palk Bay-1 and Delft-1 well locations. 


\section{THERMAL HISTORY}

Modeled present-day geothermal gradient in the Pesalai-1 and Palk Bay-1, Delft-1 and Pedro-1 wells were $25.5^{\circ} \mathrm{C} / \mathrm{km}, 25.0^{\circ} \mathrm{C} / \mathrm{km}, 21.3{ }^{\circ} \mathrm{C} / \mathrm{km}$ and $18.5^{\circ} \mathrm{C} / \mathrm{km}$, respectively. The current geothermal gradients computed using the Bottom Hole Temperatures (BHT) data by Premarathne et al. (2018) for the Pesalai-1 and Palk Bay-1, Delft-1 well locations are $26.29^{\circ} \mathrm{C} / \mathrm{km}, \quad 24.31^{\circ} \mathrm{C} / \mathrm{km}$, and $22.7^{\circ} \mathrm{C} / \mathrm{km}$, respectively. The measured values were closer in agreement with the values simulated in this study. This indicates that optimized present-day heat flow values used for this study are to be reasonably accurate. Change of formations temperatures through geological time are shown on burial history plots for the four wells (Figs. 6 and 7). According to the modelled thermal history, the maximum formation temperature of $90^{\circ} \mathrm{C}$ was recorded in the Pesalai-1 well (Fig. 6).



Fig. 6. Modelled present-day geothermal gradients for Pesalai-1, Palk Bay-1, Delft-1 and Pedro-1 wells.

\section{BURIAL HISTORY}

Burial history plots for the Pesalai-1 and Delft-1 wells (Figs. 7A and 8A) show that there was an erosional unconformity probably due to upliftment during the Albian Epoch. In addition, two more erosional unconformities, could be seen in Pesalai-1 from the Maastrichtian to the Middle Paleocene and in the Oligocene. In the Palk Bay-1 well (Fig. 7B), an erosional unconformity could be seen during the Maastrichtian to the end of the Paleocene. In the Delft-1 well, an unconformity occurred from the early Cenomanian to the end of the Eocene. This unconformity in the Pedro-1 well, occurred from the early Cenomanian up to the middle Eocene. Burial history plots for all the four wells indicate a rapid deposition from the Oligocene to present. Specially, Palk Bay-1 well (Fig. 7B), indicates that the accumulation of $2 / 3$ of its stratigraphic thickness took place during the last $45 \mathrm{Ma}$.

Albian unconformity in the Pesalai-1 and Delft1 wells (Fig. 2A and 2C), marks the end of the rifting period in the Cauvery Basin. The unconformity in Delft-1 and Pedro-1 from the early Cenomanian to the end of Eocene could be due to the upliftment associated with the buoyancy created by Reunion hotspot and intraplate deformation after the collision of the Indian plate with the Eurasian plate in the early Eocene. This collision gave rise to a rapid upliftment and erosion, which supplied a massive amount of terrigenous sediments into depocenters of the Cauvery Basin, both in the Indian side as well as in the Sri Lankan side. This is attributable to the rapid accumulation of sediments from the Oligocene to present. 
(A)

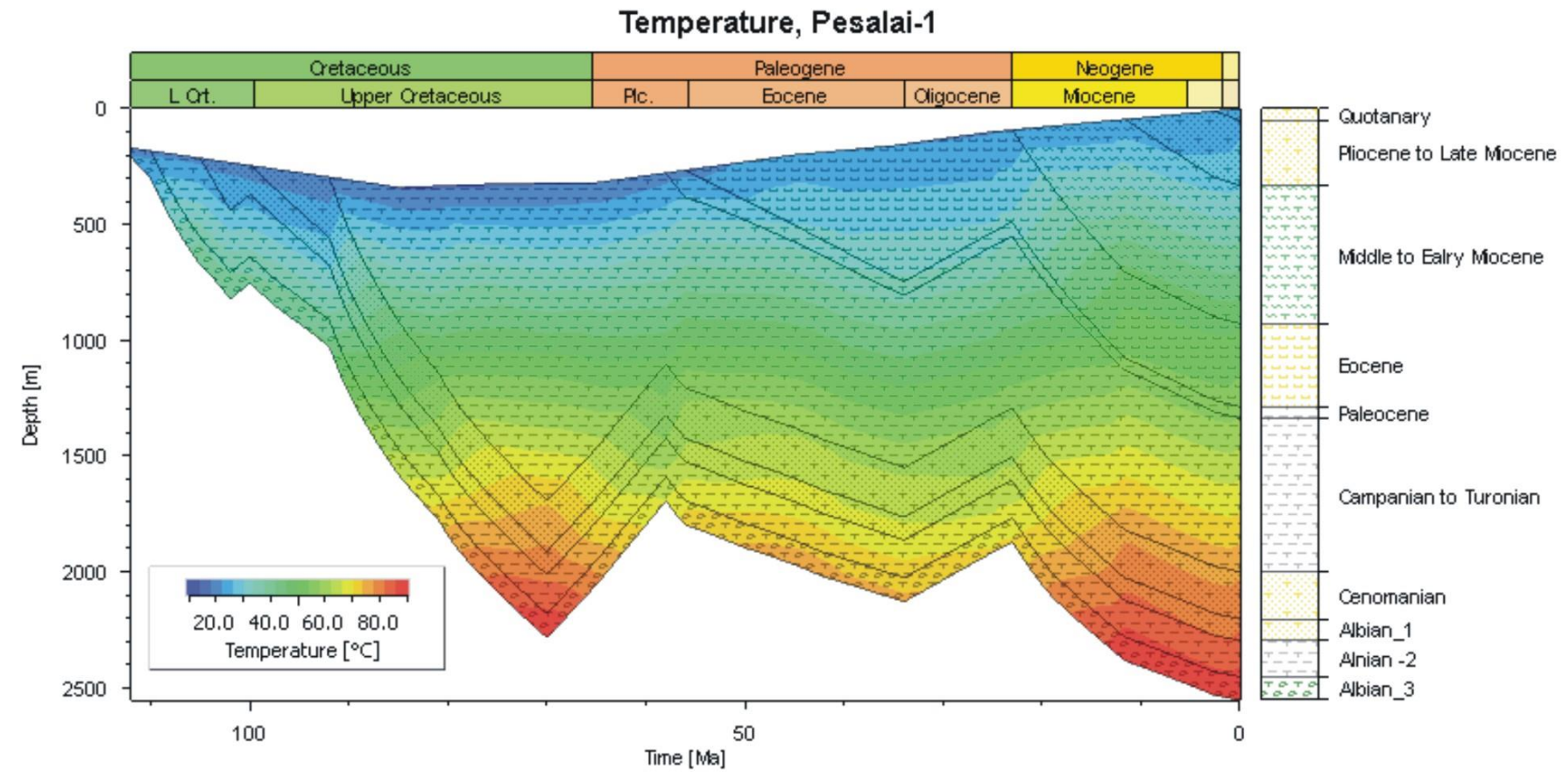

(B)

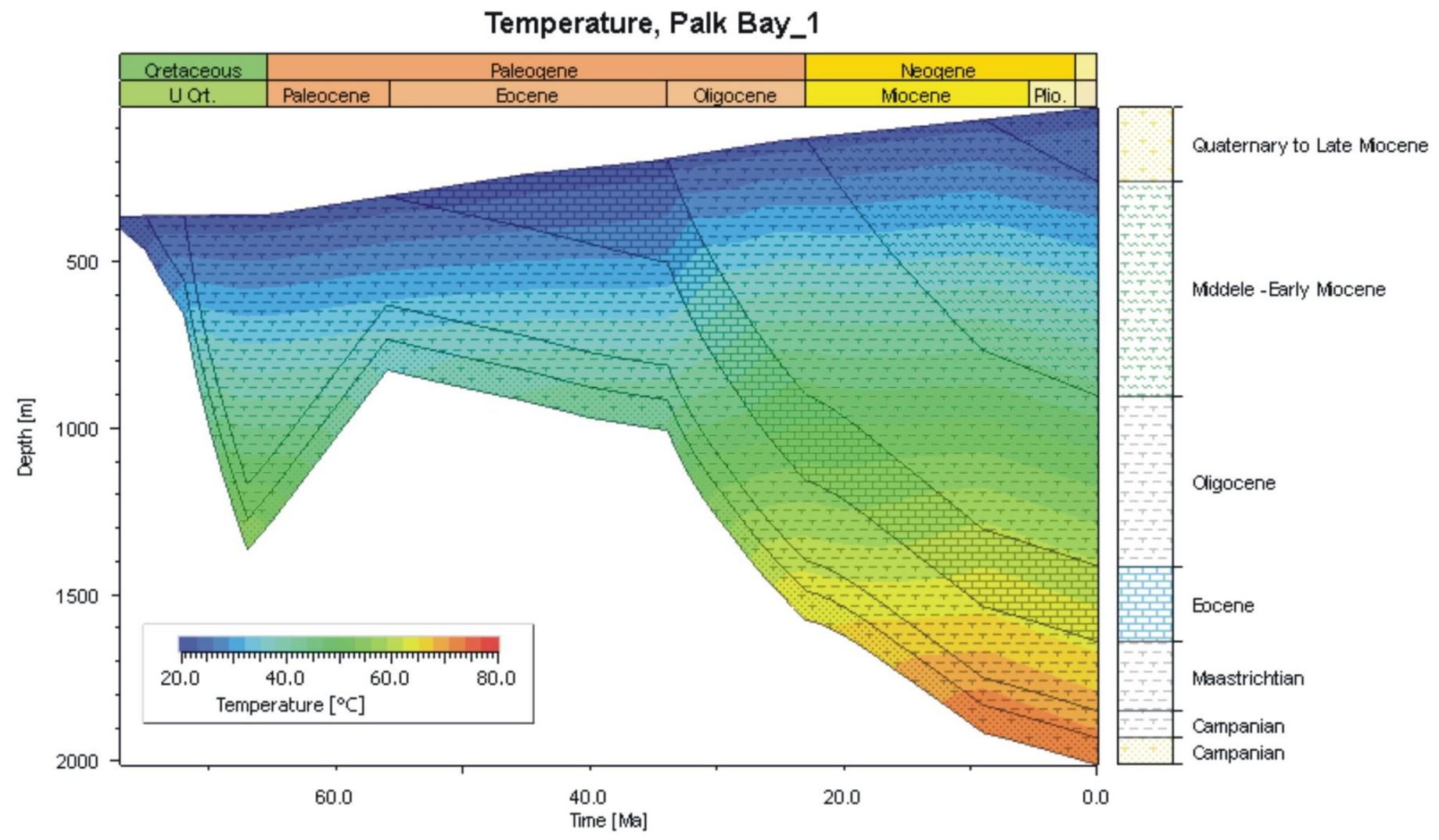

Fig. 7. Burial and thermal history plots for (A) Pesalai-1 well (B) Palk Bay 1 well. 
(A)

Temperature, Delft-1

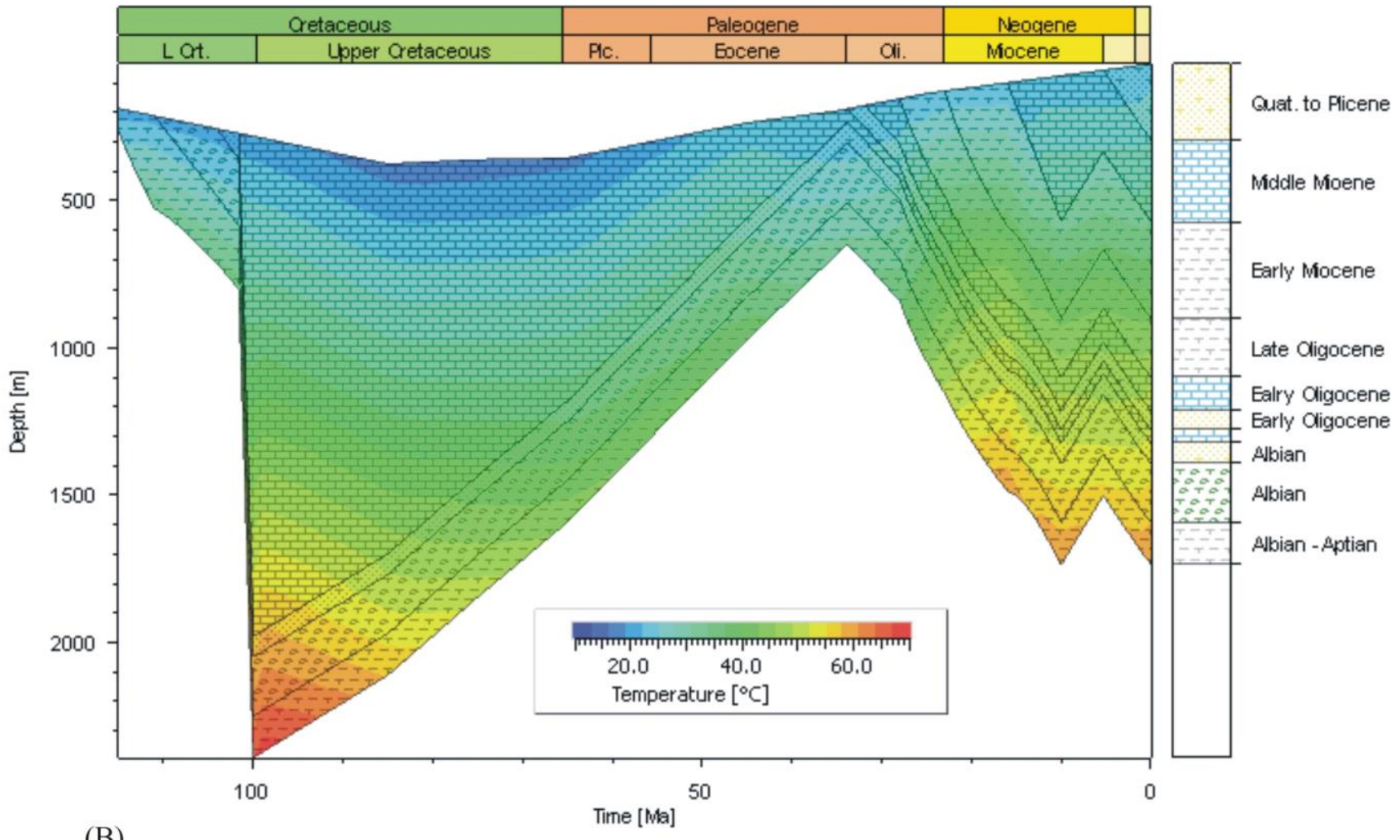

(B)

Temperature, Pedro-1

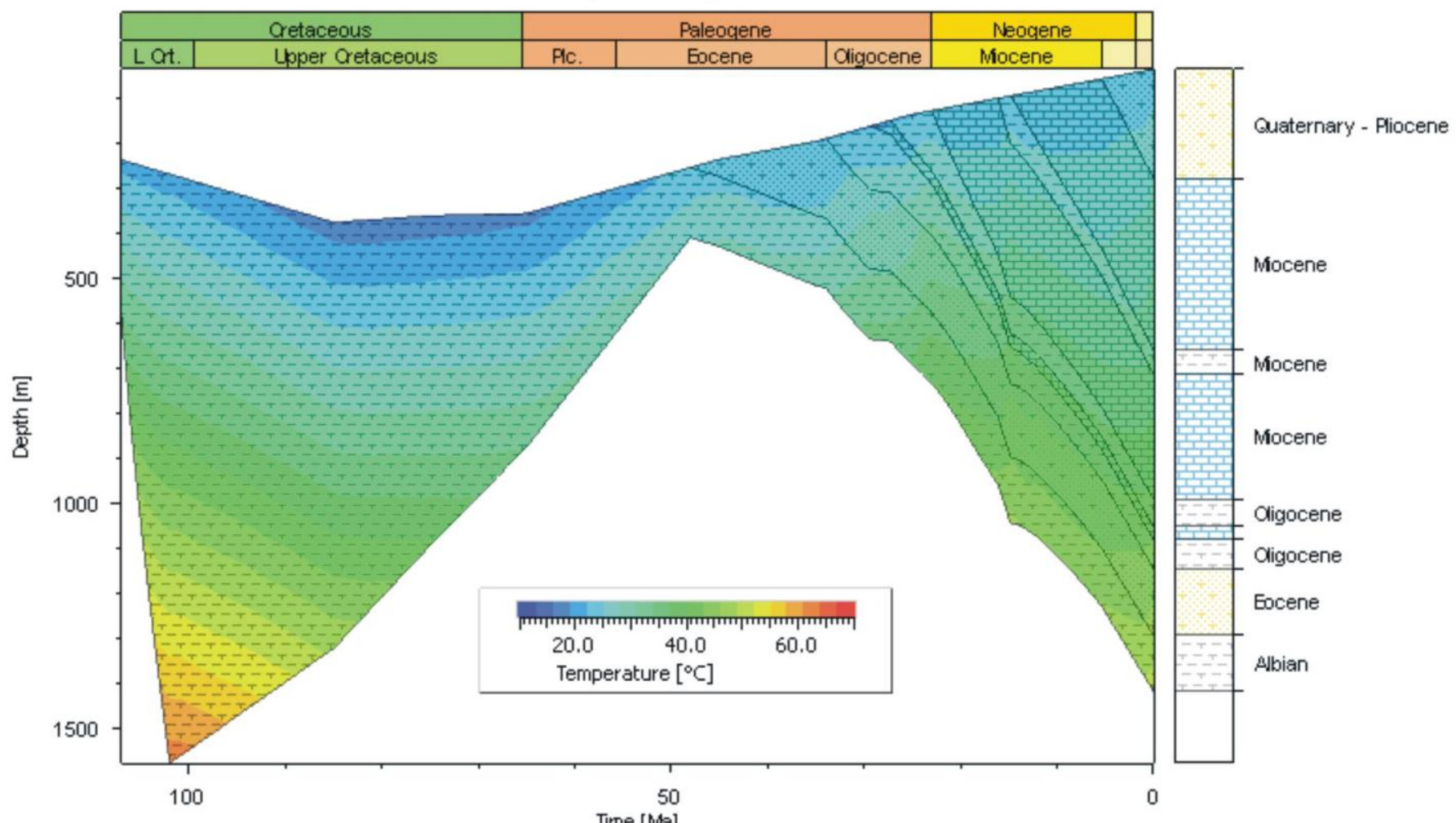

Fig. 8. Burial and thermal history plots for (A) Delft -1 well (B) Pedro-1 well. 


\section{CONCLUSIONS}

Southern part of the Cauvery Basin in Sri Lanka experienced higher heat flows than the northern part. The present-day geothermal gradients in the Pesalai-1 and Palk Bay-1, Delft-1 and Pedro1 wells are $25.5^{\circ} \mathrm{C} / \mathrm{km}, 25.0^{\circ} \mathrm{C} / \mathrm{km}, 21.3^{\circ} \mathrm{C} / \mathrm{km}$ and $18.5^{\circ} \mathrm{C} / \mathrm{km}$, respectively. The present-day geothermal gradient in the basin increases from the north to south. The highest formations temperature of around $90^{\circ} \mathrm{C}$ was recorded in Albian sediments penetrated by the Pesalai-1 well. The Pesalai area has experienced higher heat flows than the Palk Bay area. The current heat flows in the Pesalai and Palk Bay areas are around $52 \mathrm{~mW} / \mathrm{m}^{2}$ and $48 \mathrm{~mW} / \mathrm{m}^{2}$, respectively. The pre-rift heat flow in the Sri Lankan sector of the Cauvery Basin varies between 46 - 40 $\mathrm{mW} / \mathrm{m}^{2}$. Pre-rift heat flow in the Sri Lankan Cauvery Basin is slightly lower than that in the northern part of the Mannar Basin. Delft-1 and Pedro-1 well locations have undergone upliftment during the Albian to the end of the Eocene (around 100 -34 Ma). The Sri Lankan part of the Cauvery Basin has experienced relatively a higher sediment influx after the Eocene. The sediment thickness decreases towards the northern part of the basin. Sediments penetrated by the Palk Bay-1, Delft-1 and Pedro-1 wells are thermally immature. However, the Albian sediment penetrated by the Pesalai- 1 well is marginally matured and has just entered the oil window.

\section{ACKNOWLEDGEMENTS}

Author is thankful to Director General and staff of the Petroleum Resources Development Secretariat (PRDS) in Sri Lanka for providing data and support for this research and reviewers for their valuable comments on the manuscript.

\section{REFERENCES}

Bastia, R. and Radhakrishna, M. (2012) Basin Evolution and Petroleum Prospectivity of the Continental Margins of India. Elsevier. Volume, 59: $1-417$

Cantwell, T., Brown, T.E. and Mathews, D.G. (1978) Petroleum Geology of the Northwest Offshore Area of Sri Lanka. Proceedings of South Asian Petroleum Society Session, Singapore.

Chandra, K., Philip, P.C., Sridharan, P., Chopra, V.S., Rao, B. and Saha, P.K. (1991) Petroleum source- rock potentials of the Cretaceous transgressiveregressive sedimentary sequences of the Cauvery Basin. Journal of Southeast Asian Earth Sciences, 5, Nos., 1-4: 367-371.

Chakraborty, N. and Sarkar, S. (2018) Synsedimentary tectonics and facies analysis in a rift setting: Cretaceous Dalmiapuram Formation, Cauvery Basin, SE India. Journal of Palaeogeography, 7(2): 146-167.

Chari, N.M.V., Sahu, J.N., Bnerjee, B., Zutshi, P.L. and Kuldeep, C. (1995) Evolution of the Cauvery Basin, India from subsidence modelling. Marine and Petroleum Geology, 12(6): 667-675.

Chaudhuri, A., Rao, M.V., Dobriyal, J.P., Saha G.C., Chidambaram, L. Mehta, A.K., Ramana L.V. and Murthy, K.S. (2010) Prospectivity of Cauvery Basin in Deep Syn-rift Sequences, SE India. AAPG Search and Discovery Article \#10232.

Chaudhuri, A., Rao, M.V., Dobriyal, J.P., Ramana, L.V., Murthy, K.S., and Saha, G. (2009) Prospectivity of Cauvery Basin in Deep Synrift Sequences, SE India. AAPG Annual Convention and Exhibition, Denver, Colorado.

Katz, M.B. (1978) Sri Lanka in Gondwanaland and the evolution of the Indian Ocean. Geological Magazine, 115: 237-244.

Kumar, N., Zeyen, H. and Singh, A.P. (2014) 3D Lithosphere density structure of southern Indian shield from joint inversion of gravity, geoid and topography data. Journal of Asian Earth Sciences, 89: 98-107.

Lal, N.K., Siawal, A. and Kaul, A.K. (2009) Evolution of east coast of India-A plate tectonic reconstruction. Journal Geological Society of India, 73: 249-260.

Mohapatra, P., Srinivas, M., Kumar, N., Routray, P., Adhikari, S. and Daly, C. (2012) The geology and petroleum systems of the Mannar Basin, Sri Lanka. Proceedings of AAPG International Conference \& Exhibition, Singapore.

Murthy, K.S., Chaudhuri, A., Ramana, L.V, Rao, M.V. and Dobriyal, J.P. (2008) Hydrocarbon Exploration of Syn Rift Sediments in Nagapattinam Sub Basin, Cauvery Basin - A Case Study. $7^{\text {th }}$ biannual exhibition and conference on geophysics, Hyderabad: 443.

Parsons, B. and Sclater, J.G. (1977) An analysis of the variation of ocean floor bathymetry and heat flows with age. Journal of Geophysical Research, 82(5): 803- 827.

Pitman, W.C. (1978) The relationship between eustacy and stratigraphic sequences of passive margins Geological Society of America Bull. 89 (9): 1389-1403.

Premarathne, D.M.U.A.K. (2008) Petroleum Potential of Sri Lankan Cauvery Basin. 
Proceedings of Annual technical sessions of the Geological Society of Sri Lanka, Colombo, 24: 7.

Premarathne, D.M.U.A.K., Suzuki, N., Rathnayake, N.P. and Kularathne, E.K.C.W. (2013) A petroleum system in the Gulf of Mannar Basin, offshore Sri Lanka. Proceedings of annual technical sessions of Geological Society of Sri Lanka, Peradeniya, 29: 9-12.

Premarathne, U. (2015) Petroleum Potential of the Cauvery Basin, Sri Lanka, Journal of the Geological Society of Sri Lanka, 17: 41-52.

Premarathne, U., Suzuki, N., Ratnayake, N. and Kularathne, C. (2016) Burial and thermal history modelling of the Mannar Basin, offshore Sri Lanka. Journal of Petroleum Geology, 39(2): 193214.

Premarathne, U. (2017) Present day heat flows in the Cauvery basin, Sri Lanka. Proceedings of the annual technical sessions of Geological Society of Sri Lanka, 33: 18.

Ramana, M.V., Subrahmanyam, V., Sarma, K.V.L.N.S. and Seshavataram, B.T.V. (1995) Marine magnetic studies over a lost wellhead in Palk Bay, Cauvery Basin, India. Journal of the Geological Society of India, 45(2): 201-208.

Rana, M.S., Chakraborty, C., Sharma, R. and Giridhar, M. (2008) Mannar volcanicsimplications for Madagascar breakup. Proceedings of $7^{\text {th }}$ International Conference and Exposition on Petroleum Geophysics, Hyderabad.

Raju, D.S.N., Reddy, A.N., Jaiprakash, B.C., Gilbert, H. and Sangwar, D.P. (2018) Age and Paleoenvironmental Evolution of the Syn-rift Fill Sediments in East Coast Basins of India, Oil and Natural Gas Company Bulletin, 52(2): 127-148.

Ramana, M.V., Subrahmanyam, V., Sarma, K.V.L.N.S. and Seshavataram, B.T.V. (1995) Marine Magnetic Studies over a lost wellhead in Palk Bay, Cauvery Basin, India., Journal of Geological Society of India, 45: 201-208.

Rao, M.V., Chidambaram, L., Bharktya, D. and Janardhanan, M. (2010) Integrated analysis of Late Albian to Middle Miocene sediments in Gulf of Mannar shallow waters of the Cauvery Basin, India: A sequence stratigraphic approach. Proceedings of $8^{\text {th }}$ biennial international conference and exposition on petroleum geophysics, Hyderabad.

Ratnayake, A.S., and Sampei, Y. (2015) Characterization of organic matter and depositional environment of the Jurassic small sedimentary basins exposed in the northwest onshore area of Sri Lanka. Researches in Organic Geochemistry 31, 15-28.

Reeves, C.V., Sahu, B.K. and Diewit, M.J. (2002) A re-examination of the paleo-position of Africa's eastern neighbors in Gondwana, Journal of African Earth Sciences, 34: 101-108.
Sastri, V.V. Sinha, R.N., Singh, G. and Murti, K.V.S. (1973) Stratigraphy and tectonics of sedimentary basins on east coast of peninsular India, AAPG Bull, 57: 655-678.

Sastri, V.V., Venkatachala, S.B.S. and. Narayananthe, V. (1981) Evolution of the East Coast of India. Palaeogeography, Palaeoclimatology, Palaeoecology, 36: 23-54.

Torsvik, T.H., Carlos, D., Mosar, M., Cocks, L.R.M. and Malme, T. (2002) Global reconstructions and North Atlantic paleogeography 440 Ma to Recent In: Eide, E.A. (Coord.), BATLAS-Mid Norway plate reconstruction atlas with global and Atlantic perspective. Geological survey of Norway, 18-39.

Wygrala, B.P. (1989) Integrated Study of an Oil Field in the Southern Po Basin, Northern Italy: Ph.D. dissertation, University of Cologne, 217.

Yoshida, M., Funaki, M. and Vitanage, P.W. (1992) Proterozoic to Mesozoic east Gondwana: the juxtaposition of India, Sri Lanka, and Antarctica. Tectonics, 11(2): 381-391.

Zakharov, Y.D., Shigeta, Y., Nagendra, R., Safronov, P.P., Smyshlyaeva, O.P., Popov, A.M., Velivetskaya, T.A. and Afanasyeva, T.B. (2009) Cretaceous climatic oscillations in the southern palaeolatitudes: new stable isotope evidence from India and Madagascar. In: Hart, M.B. (Ed.), International Symposium on the Cretaceous System, University of Plymouth, 8: 3. 
